\title{
Conceptual Analysis on Higher Education Strategies for Various Tech-Generations
}

\author{
P. S. Aithal ${ }^{1} \&$ Shubhrajyotsna Aithal ${ }^{2}$ \\ ${ }^{1}$ College of Management \& Commerce, Srinivas University, Mangalore - 575 001, INDIA \\ OrcidID: 0000-0002-4691-8736; E-mail: psaithal@gmail.com \\ ${ }^{2}$ Dept. of Chemistry, College of Engineering \& Technology, Srinivas University, Mangalore- \\ 575001, INDIA \\ OrcidID: 0000-0003-1081-5820; E-mail: shubhraaithal@gmail.com
}

Area/Section: Technology Management.

Type of the Paper: Conceptual Research.

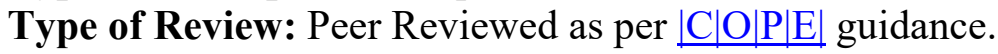

Indexed in: OpenAIRE.

DOI: http://doi.org/10.5281/zenodo.3940590.

Google Scholar Citation: $\underline{\text { IJMTS. }}$

\section{How to Cite this Paper:}

Aithal, P. S., \& Aithal, Shubhrajyotsna. (2020). Conceptual Analysis on Higher Education Strategies for Various Tech-Generations. International Journal of Management, Technology, and Social Sciences (IJMTS), 5(1), 335-353. DOI: http://doi.org/10.5281/zenodo.3940590.

International Journal of Management, Technology, and Social Sciences (IJMTS)

A Refereed International Journal of Srinivas University, India.

(C) With Authors.

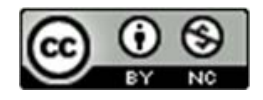

This work is licensed under a Creative Commons Attribution-Non-Commercial 4.0 International License subject to proper citation to the publication source of the work.

Disclaimer: The scholarly papers as reviewed and published by the Srinivas Publications (S.P.), India are the views and opinions of their respective authors and are not the views or opinions of the SP. The SP disclaims of any harm or loss caused due to the published content to any party. 


\title{
Conceptual Analysis on Higher Education Strategies for Various Tech-Generations
}

\author{
P. S. Aithal ${ }^{1} \&$ Shubhrajyotsna Aithal ${ }^{2}$ \\ ${ }^{1}$ College of Management \& Commerce, Srinivas University, Mangalore - 575 001, INDIA \\ OrcidID: 0000-0002-4691-8736; E-mail: psaithal@gmail.com \\ ${ }^{2}$ Dept. of Chemistry, College of Engineering \& Technology, Srinivas University, Mangalore- \\ 575001, INDIA \\ OrcidID: 0000-0003-1081-5820; E-mail: shubhraaithal@gmail.com
}

\begin{abstract}
Higher education is finding importance throughout the globe due to two reasons that include challenges to increase Gross Enrolment Ratio (GER) towards 100\% and the possibility of further HE system innovations due to drastic changes in technology and the creativity of new Tech-generations. In this paper, we made a detailed analysis of the effect of technology on industry and the creation of new tech generations in society. The predictive analysis methodology is used for discussing the effect of technologies on industries and its effects on the creation of new tech generations. Finally, the possible higher education strategies to fulfil the anticipated desires of the tech-generations in society are analysed. Based on the analysis a set of postulates are suggested to integrate technology with the higher education system to develop industry acceptable qualified professionals to serve satisfactorily in so-called Tech-society.
\end{abstract}

Keywords: Higher education strategies, Tech-Generations, Generation Y, Generation Z, Generation A, Industry 5.0, Education 5.0, Education technology, Predictive analysis.

\section{INTRODUCTION :}

Higher education has an objective of confidence building of youths by enhancing the knowledge, skills, and experience along with human values [1]. Higher education is finding importance throughout the globe due to two reasons that include challenge to increase Gross Enrolment Ratio (GER) towards $100 \%$ and the possibility of further HE system innovations due to drastic changes in technology and the creativity of learners. As supporting technology changes with time, the attitude and perception of learners in higher education in terms of mode, method, and pedagogy are also changes. Such changes in higher education system is required to cater new generation of learners to satisfy them to extract further new knowledge, skills, and expectations in the process of providing further confidence in the society for human prosperity.

In this paper, we made detailed analysis on various technology generations, effect of technology on industry and birth of various industry generations, and the impact of various innovations in industry on creation of new tech generations in the society. The predictive analysis methodology is used for discussing the effect of technologies on industries and its effect on creation of new tech generations. The study further focuses on effect of industry generations on higher education modes, models, and pedagogy for different tech-generations.

Finally, the possible higher education strategies to fulfil the anticipated desires of the tech-generations in the society is analysed. Based on the analysis a set of postulates are suggested to integrate technology in higher education process to develop industry acceptable qualified professional in higher education to serve satisfactorily in so called Techsociety.

\section{OBJECTIVES \& AGENDA :}

This paper analyses the concept of various techhuman generations and industry generations and interrelations expected between them. The objective includes : 
(1) To identify various technology generations, industry generations, and their characteristics.

(2) To review various technology impacts on education industry \& their capabilities.

(3) To identify and review various tech-human generations \& their characteristics

(4) To predict next generations of technology, industry, and tech-human generation based on predictive analysis.

(5) To predict future characteristics of these three generations and their interconnection for human prosperity.

\section{TECHNOLOGY GENERATIONS \& CHARACTERISTICS :}

The historical development of technology based on innovative efforts of human beings starting from 4,000 BC lead to various Technology generations. The twelve technology generations in history until the $21^{\text {st }}$ century are listed first time by considering their characteristics and the corresponding era in table 1. The first-generation technology called mechanization technology comprises of tools and weapons made by different metals invented during 4,000 to $2,800 \mathrm{BC}$ including bronze and copper. The first-generation technology also includes printing of information by inventing letters and hence is also called the Knowledge era. The second generation technology is also steam engine technology and is responsible for the industrial era during the $18^{\text {th }}$ century. The third generation technology called electricity technology involved in power generation and usage and popularly reached many people in the $19^{\text {th }}$ century. The fourth generation technology called automobile technology provided solutions to long distance commuting \& transportation became publicly available in the $20^{\text {th }}$ century. The fifth generation technology called airplane \& space technology supported for international travel \& transportation and space travel became practicable in the $20^{\text {th }}$ century. The sixth generation technology is popularly known as telephone technology used for distance communication in the $20^{\text {th }}$ century. The seventh generation technology called television technology is used in the last part of the $20^{\text {th }}$ century worldwide for video communication. The eight generation technology called computer technology used for data processing and reached the common man in the second half of the $20^{\text {th }}$ century. Internet technology is considered as ninth generation technology and it became popular for online information sharing and access by interconnecting many networks and organizations for e-business in the last quarter of the $20^{\text {th }}$ century. The tenth-generation technology called Mobile Communication \& Biotechnology focuses on ubiquitous communication, bio-engineering, \&gene therapy again developed in the last part of the $20^{\text {th }}$ century. The eleventh and twelfth generation technologies belonging to the $21^{\text {st }}$ century Information Communication \& Computation (ICCT) underlying Technologies with focus on ubiquitous computing \& communication, and total automation [2] and nanotechnology with a focus on optimum solutions to nutritious food, drinking water, renewable energy, Nanomedicine \& Therapy, respectively [35].

Table 1 : Technology Generations and their characteristics

\begin{tabular}{|l|l|l|l|l|}
\hline $\begin{array}{l}\text { S. } \\
\text { No. }\end{array}$ & Generations & Technology & Characteristics & Era \\
\hline 1 & First Generation & $\begin{array}{l}\text { Mechanization } \\
\text { Technology }\end{array}$ & $\begin{array}{l}\text { Tools, Weapons, \& Printing } \\
\text { (knowledge Era) }\end{array}$ & $\begin{array}{l}4,000-2,800 \\
\text { BC }\end{array}$ \\
\hline 2 & Second Generation & $\begin{array}{l}\text { Steam Engine } \\
\text { Technology }\end{array}$ & $\begin{array}{l}\text { Industrial Revolution } \\
\text { (Industrial era) }\end{array}$ & $18^{\text {th }}$ Century \\
\hline 3 & Third Generation & Electricity Technology & Power generation \& Usage & $19^{\text {th }}$ Century \\
\hline 4 & Fourth Generation & Automobile Technology & $\begin{array}{l}\text { Long distance commuting \& } \\
\text { Transportation }\end{array}$ & $20^{\text {th }}$ Century \\
\hline 5 & Fifth Generation & $\begin{array}{l}\text { Airplane \& space } \\
\text { Technology }\end{array}$ & $\begin{array}{l}\text { International Travel \& } \\
\text { Transportation }\end{array}$ & $20^{\text {th }}$ Century \\
\hline 6 & Sixth Generation & Telephone Technology & Distance communication & $20^{\text {th }}$ Century \\
\hline 7 & Seventh & Television Technology & Video communication & $20^{\text {th }}$ Century \\
\hline
\end{tabular}

P. S. Aithal, et al. (2020); www.srinivaspublication.com 


\begin{tabular}{|l|l|l|l|l|}
\hline & Generation & & & \\
\hline 8 & Eight Generation & Computer Technology & Data Processing & $20^{\text {th }}$ Century \\
\hline 9 & Ninth Generation & Internet Technology & $\begin{array}{l}\text { Data \& Information } \\
\text { Communication, E-business }\end{array}$ & $20^{\text {th }}$ Century \\
\hline 10 & Tenth Generation & $\begin{array}{l}\text { Mobile Communication } \\
\text { \& Biotechnology }\end{array}$ & $\begin{array}{l}\text { Ubiquitous communication \& } \\
\text { Bio-engineering, Gene Therapy, }\end{array}$ & $20^{\text {th }}$ Century \\
\hline 11 & $\begin{array}{l}\text { Eleventh } \\
\text { Generation }\end{array}$ & $\begin{array}{l}\text { Information } \\
\text { Communication \& } \\
\text { Computation (ICCT) } \\
\text { underlying Technologies }\end{array}$ & $\begin{array}{l}\text { Ubiquitous computing\& } \\
\text { Communication, and Total } \\
\text { Automation }\end{array}$ & $21^{\text {st }}$ Century \\
\hline 12 & $\begin{array}{l}\text { Twelfth } \\
\text { Generation }\end{array}$ & Nanotechnology & $\begin{array}{l}\text { Solutions to nutritious food, } \\
\text { drinking water, renewable } \\
\text { energy, Nanomedicine \& } \\
\text { Therapy }\end{array}$ & $21^{\text {st }}$ Century \\
\hline
\end{tabular}

The eleventh and twelfth generations of technology are combinedly named as Universal technologies [4] and are $21^{\text {st }}$ century technologies. The universal technologies comprising of ICCT underlying technologies and nanotechnology are able to provide complete product and service automation and are considered as a boon to mankind if managed strategically.

\section{INDUSTRY GENERATIONS \&} CHARACTERISTICS :

An industry in society refers to a group of companies which primarily deal with related business activities. An industry represents all entities that are engaged in activities like manufacturing or production of goods and services with an objective of making a profit. There are various industries in the manufacturing and service sectors and they use suitable technology for their operations. Depending on the type of general- purpose technology used, industries are classified under different generations as industry 1.0, industry 2.0, industry 3.0, etc. Table 2 lists various industry generations along with the technologies used and their characteristics. Industry 1.0 used water and steam-based power system for mechanized operations. Industry 2.0 used electricity and assembly lines for the manufacturing of goods with mass production features. Industry 3.0 used computer and communication technology for the automation of production processes. Industry 4.0 uses the internet of things (IoT) and 3D printing technologies for mass customization of production processes, and Industry 5.0 is expected to use ICCT underlying technologies including Artificial intelligence \& Virtual reality and Nanotechnology for Mass Automation and 3D production using Nanotechnology and ICCT controlled Super Intelligent Machine systems.

Table 2 : Technology impact on Industry

\begin{tabular}{|c|c|c|c|}
\hline S. No. & $\begin{array}{l}\text { Progress of } \\
\text { Industry }\end{array}$ & Characteristics & Technology used \\
\hline 1 & Industry 1.0 & Mechanization - Energy based. & Water \& Steam Power Systems \\
\hline 2 & Industry 2.0 & $\begin{array}{l}\text { Mass Production }- \text { Knowledge } \\
\text { based. }\end{array}$ & Electricity and assembly line \\
\hline 3 & Industry 3.0 & $\begin{array}{l}\begin{array}{l}\text { Automation } \\
\text { based. }\end{array} \\
\text { Processes }-\end{array}$ & $\begin{array}{l}\text { Computer and } \\
\text { technology }\end{array}$ Communication \\
\hline 4 & Industry 4.0 & $\begin{array}{l}\text { Mass Customization - Experience } \\
\text { based. }\end{array}$ & Internet of Things (IoT) and 3D printing \\
\hline 5 & $\begin{array}{l}\text { Industry } 5.0 \\
\text { (Predicted) [6] }\end{array}$ & $\begin{array}{l}\text { Mass Automation and } 3 \mathrm{D} \\
\text { production using Nanotechnology }\end{array}$ & $\begin{array}{l}\text { ICCT underlying technologies including } \\
\text { Artificial intelligence \& Virtual reality }\end{array}$ \\
\hline
\end{tabular}




\begin{tabular}{|l|l|l|l|}
\hline & $\begin{array}{l}\text { and ICCT controlled Super } \\
\text { Intelligent Machine systems - } \\
\text { Intelligence based. }\end{array}$ & and Nanotechnology \\
\hline
\end{tabular}

\section{EDUCATION GENERATIONS \& CHARACTERISTICS BASED ON TECHNOLOGY IMPACT :}

Education is a part of the service industry and is very important in imparting knowledge and skills systematically to the growing human beings in the developing society. Education uses various technologies for its effectiveness in fulfilling its objectives. Table 3 lists some of the generations in the industry based on used technology and observed characteristics. Education 1.0 uses the printing of letters using ink on papers or palm leaf with an objective of information accumulation. Education 2.0 uses typewritten (printed)

\begin{abstract}
technology on paper or books for reading and understanding. Education 3.0 uses computers, information storage, and communication technology for automated mass learning using MOOC. Education 4.0 which is the current innovative model uses MOOC and Internet of things (IoT) based digital technologies. It is predicted that future education will be based on Education 5.0 is expected to use ICCT underlying technologies [7-9] including artificial intelligence and virtual reality along with nanotechnology. This leads to mass automation using nanotechnology and ICCT controlled Super Intelligent Machine systems [5].
\end{abstract}

Table 3 : Technology impact on education industry

\begin{tabular}{|l|l|l|l|}
\hline $\begin{array}{l}\text { S. } \\
\text { No. }\end{array}$ & $\begin{array}{l}\text { Progress of Education } \\
\text { Industry }\end{array}$ & Characteristics & Technology used \\
\hline 1 & Education 1.0 & $\begin{array}{l}\text { Reading \& writing - Information } \\
\text { accumulation. }\end{array}$ & $\begin{array}{l}\text { Letters using ink on paper or Palm } \\
\text { leaf }\end{array}$ \\
\hline 2 & Education 2.0 & $\begin{array}{l}\text { Reading and understanding - } \\
\text { Knowledge based study. }\end{array}$ & $\begin{array}{l}\text { Paper \& Book based type written } \\
\text { knowledge management technology }\end{array}$ \\
\hline 3 & Education 3.0 & $\begin{array}{l}\text { Automated mass learning using } \\
\text { MOOC-Skill based training. }\end{array}$ & $\begin{array}{l}\text { Computer, storage and } \\
\text { Communication technology }\end{array}$ \\
\hline 4 & Education 4.0 & $\begin{array}{l}\text { Mass Customization using } \\
\text { research and innovation - } \\
\text { Experience based learning. }\end{array}$ & $\begin{array}{l}\text { MOOC Internet of Things (IoT) } \\
\text { based digital technologies }\end{array}$ \\
\hline 5 & Education 5.0 [6] & $\begin{array}{l}\text { Mass Automation using } \\
\text { Nanotechnology and ICCT } \\
\text { controlled Super Intelligent } \\
\text { Machine systems - Intelligence } \\
\text { based. }\end{array}$ & $\begin{array}{l}\text { ICCT underlying technologies } \\
\text { including Artificial intelligence \& } \\
\text { Virtual reality and Nanotechnology }\end{array}$ \\
\hline
\end{tabular}

\section{TECH-HUMAN GENERATIONS \& CHARACTERISTICS :}

Based on use of technology in day to day life, human generations are classified into different types. This include First tech-human generation called silent generation, Second generation techhuman generation called boomers, Third techhuman generation called Generation X, Fourth tech-human generation called Generation $\mathrm{Y}$ or
Millennials, and Fifth tech-human generation called Generation Z or iGen or Centennials. Silent generation consists of people of age group who born before 1944 and their habits are reading News Paper, doing business in Cash \& Barter transactions, etc. Boomers also called baby boomers are group of people born between 1945 to 1964 having habits of hearing Radio, using branch banking for financial transactions, and use cash for small transactions. Generation $\mathrm{X}$ is third tech- 
generation born between 1965 and 1979 with the habits of watching TV \& using Facebook. These people are Tech-savvy but prefers personal financial transactions. The fourth tech-generation is called Generation Y (or Millennials). They are born between 1980 to 1994 with habit of using cable-based Internet, and Internet based online financial transactions, etc. The fifth techgeneration is called Generation Z (or iGen or Centennials) and are born between 1995 - 2015 with tech habit of using mobile devices for communication, online games for entertainment, and mobile banking for financial transactions. It is predicted that the sixth tech-generation comprises of children born after 2015 will be exposed to next generation technology including artificial intelligence and virtual reality and expected to develop habits related to such technologies can be called as tech-generation A [6] or Alpha [33].

Table 4 : Tech-human generations (Tech-Generations)

\begin{tabular}{|c|c|c|c|}
\hline S. & Generation & Born Period & Habits \\
\hline 1 & $\begin{array}{l}\text { Silent Generation (or } \\
\text { Traditionalist) }\end{array}$ & $1930-1944$ & Read News Paper, Cash \& Barter transactions \\
\hline 2 & Boomers & $1945-1964$ & $\begin{array}{l}\text { Watch Radio, Branch banking, use cash for small } \\
\text { transactions }\end{array}$ \\
\hline 3 & Generation X & $1965-1979$ & $\begin{array}{l}\text { Watch TV \& Facebook users, Tec savvy but prefers } \\
\text { personal transactions }\end{array}$ \\
\hline 4 & $\begin{array}{lll}\text { Generation } & \text { Y } & \text { (or } \\
\text { Millennials) } & & \end{array}$ & $1980-1994$ & Cable based Internet, Internet based transactions \\
\hline 5 & $\begin{array}{l}\text { Generation } \mathrm{Z} \\
\text { (or iGen } \\
\text { Centennials) }\end{array}$ & $1995-2015$ & Mobile devices, Online games, Mobile banking \\
\hline 6 & $\begin{array}{l}\text { Generation A } \\
\text { (Artificial intelligence } \\
\text { generation) [6] }\end{array}$ & 2016 onwards & $\begin{array}{l}\text { Artificial Intelligence and virtual reality embedded } \\
\text { mobile devices }\end{array}$ \\
\hline
\end{tabular}

\section{RELATED WORK ON TECH GENERATIONS:}

Some of the related research works published as scholarly articles on different areas and issues on Tech-generations are listed in table 5.

Table 5 :Various scholarly publications on different Areas and issues on Tech-generations

\begin{tabular}{|l|l|l|l|}
\hline S. No. & Areas & Issues & References \\
\hline 1 & Technology Generation & $\begin{array}{l}\text { Internet generation comparison with } \\
\text { mechanical generation }\end{array}$ & $\begin{array}{l}\text { Sackmann, R., et al. } \\
(2013) \text { [10] }\end{array}$ \\
\hline 2 & Net Generation & $\begin{array}{l}\text { Tech savviness and information } \\
\text { seeking behaviour of net generation }\end{array}$ & $\begin{array}{l}\text { Combes, B. A. (2012). } \\
{[11]}\end{array}$ \\
\hline 3 & Generation X & Understanding generation X employees & $\begin{array}{l}\text { Kupperschmidt, B. R. } \\
\text { (1998). [12] }\end{array}$ \\
\hline 4 & Generation X & New learning strategies & $\begin{array}{l}\text { Brown, B. L. } \\
(1997) . ~[13]\end{array}$ \\
\hline 5 & Generation X & The Way They Do the Things They Do & Cannon, D. (1991). [14] \\
\hline 6 & Generation X & $\begin{array}{l}\text { Attitudinal differences between } \\
\text { generation-x and older employees }\end{array}$ & $\begin{array}{l}\text { Ferres, N., et al. (2003). } \\
\text { [15] }\end{array}$ \\
\hline 7 & Generation X & What they think and what they plan to & Losyk, B. (1997). [16] \\
\hline
\end{tabular}




\begin{tabular}{|c|c|c|c|}
\hline & & do & \\
\hline 8 & Generation Y & Managing Generation $\mathrm{Y}$ & Eisner, S. P. (2005). [17] \\
\hline 9 & Generation Y & $\begin{array}{l}\text { Ethical ideology and its potential } \\
\text { workplace implications }\end{array}$ & $\begin{array}{l}\text { VanMeter, R. A. (2013). } \\
\text { [18] }\end{array}$ \\
\hline 10 & Generation Y & $\begin{array}{l}\text { Generation Y in the workforce: } \\
\text { Managerial challenges }\end{array}$ & Meier, J. (2010). [19] \\
\hline 11 & Generation Y & $\begin{array}{l}\text { Examination of work attitude } \\
\text { differences of Generation Y employees }\end{array}$ & Solnet, D. (2012). [20] \\
\hline 12 & Generation Y & $\begin{array}{l}\text { Psychographic analysis of Generation } \\
\text { Y college students }\end{array}$ & $\begin{array}{l}\text { Wolburg, J. M. (2001). } \\
\text { [21] }\end{array}$ \\
\hline 13 & Generation Y & $\begin{array}{l}\text { Teaching to Generation } \mathrm{Y} \text { - challenges } \\
\text { and opportunities }\end{array}$ & $\begin{array}{l}\text { Eckleberry-Hunt, J. } \\
\text { (2011) [22] }\end{array}$ \\
\hline 14 & Generation Y & $\begin{array}{l}\text { Investigating the specificity of } \\
\text { generation Y versus other generations }\end{array}$ & $\begin{array}{l}\text { Pînzaru, F. et al. (2016) } \\
\text { [23] }\end{array}$ \\
\hline 15 & Generation Z & $\begin{array}{l}\text { Moving on from millennials: Preparing } \\
\text { for generation } \mathrm{Z}\end{array}$ & Shatto, B. (2016). [24] \\
\hline 16 & Generation Z & $\begin{array}{l}\text { Understanding the generation } \mathrm{Z} \text { : the } \\
\text { future workforce }\end{array}$ & Singh, A. P. (2016). [25] \\
\hline 17 & Generation Z & The characteristics of Generation Z & Dolot, A. (2018). [26] \\
\hline 18 & Generation Z & $\begin{array}{l}\text { Generation } \mathrm{Z} \text { and its perception of } \\
\text { work }\end{array}$ & $\begin{array}{l}\text { Iorgulescu, M. C. (2016). } \\
\text { [27] }\end{array}$ \\
\hline 19 & Generation $\mathrm{Z}$ & $\begin{array}{l}\text { Teaching Millennials and Generation } \\
\text { Z: Bridging the generational divide }\end{array}$ & Shatto, B. (2017). [28] \\
\hline 20 & Generation Z & $\begin{array}{l}\text { Working with generations } \mathrm{X} \text { and } \mathrm{Y} \text { in } \\
\text { generation } \mathrm{Z} \text { period }\end{array}$ & Berkup, S. B. (2014). [29] \\
\hline 21 & Generation Z & $\begin{array}{l}\text { Understanding Generation } \mathrm{Z} \text { students to } \\
\text { promote a contemporary learning } \\
\text { environment }\end{array}$ & Mohr, K. A. (2017). [30] \\
\hline 22 & Generation Z & The challenge of teaching generation $\mathrm{Z}$ & Cilliers, E. J. (2017). [31] \\
\hline 23 & Generation Z & $\begin{array}{l}\text { Generation z's teachers and their digital } \\
\text { skills }\end{array}$ & Cruz, F. J. F. (2016) [32] \\
\hline 24 & Generation Alpha & Not Clear reason & $\begin{array}{l}\text { Nagy, Á. Et al. (2017) } \\
\text { [33] }\end{array}$ \\
\hline 25 & Generation A & $\begin{array}{l}\text { Children born during } 2016 \text { onwards in } \\
\text { the era of Artificial Intelligence }\end{array}$ & $\begin{array}{l}\text { Aithal P. S. et al. (2020) } \\
{[6]}\end{array}$ \\
\hline
\end{tabular}

\section{TRAITS OF INITIAL GENERATIONS INCLUDING GENERATION X :}

\subsection{Silent Generation :}

The silent generation also called Generation S, encompasses people born between 1930 to 1945 . They are also called Traditionalists. Currently majority of them are 75 to 90 years and enjoying their retired life. These people unprivileged in terms of technology-based comforts. This generation suffered a lot due to conflict in ideas, desires, and morals. They did not speak their minds out, unadventurous and did not take any risks in life
Some of the traits of Silent generation are :

(1) They were loyal to their employers and the country and hence not changing the jobs frequently. (2) Loyal to authorities, good team players and did not start any conflict in working place.

(3) They had no access to the technology like other modern generations.

(4) They preferred traditional educational institutions for their study and had no access to online education.

(5) Silent generation has used Black Slate and Processed dry leaf for writing \& communication during their education phase of their childhood. 


\subsection{Tech-Generation Boomers :}

Boomers also called baby boomers or Generation $\mathrm{B}$ are born after second world war and they were large in number compared to silent generation [34]. Baby boomers are one of the largest learning generations today, as new retirees leave the workforce and look to take up new skills and online studies. Some of the traits of Boomer generation are :

(1) Motivated to learn through strong their strong work ethics.

(2) Confident in learning new things.

(3) Competitive in self-improvement and personal growth.

(4) Goal centric due to focussed and motivated.

(5) Resourceful due to problem solving skills.

(6) Team oriented and disciplined.

(7) Baby boomers used paper based notebook for information gathering, writing \& communication during their education phase of their childhood.

\subsection{Tech-Generation $X$ :}

Generation $\mathrm{X}$ is also called lost and forgotten generation whose birth years by falling between 1961 and 1981. Currently they are in the age between 38-58 years. Some of the traits of generation $\mathrm{X}$ are :

(1) Their high entrepreneurial ability developed probably due to non-availability of suitable Job.

(2) They are hardworking generation compared other generations.

(3) Most of them are currently part of working force in every country.

(4) They are highly-educated, Ethnically Diverse, Individualistic in nature.

(5) They are often criticized for a snarky and casual disdain for authority.

(6) They are Tech-savvy and became matured during the explosion of telephone and mobile technology in the world.

(7) They are capable to balance various responsibilities in life including proper balancing of family life and work life.

(8) They born during anti-child phase due to abundantly availed birth control facilities and hence had unprotected childhood.

(9) They have used Xerox /Copying for information storage and telephone technology for communication during their education phase of their childhood.

The following table 6 , consists of some of the habits and correlated with frequently used education technology.

Table 6 : Habits and frequently use education technology of various generations

\begin{tabular}{|l|l|l|l|}
\hline $\begin{array}{l}\text { S. } \\
\text { No. }\end{array}$ & Generation & Habits & Frequently used Education Technology \\
\hline 1 & $\begin{array}{l}\text { Silent Generation } \\
\text { (or Traditionalist } \\
\text { or Generation S) } \\
(1930-1944)\end{array}$ & $\begin{array}{l}\text { Read News Paper, Cash \& } \\
\text { Barter transactions }\end{array}$ & $\begin{array}{l}\text { Black Slate and Processed dry leaf for writing \& } \\
\text { communication }\end{array}$ \\
\hline 2 & $\begin{array}{l}\text { Boomers } \\
\text { Generation B } \\
(1945-1964)\end{array}$ & $\begin{array}{l}\text { Watch Radio, Branch } \\
\text { banking, use cash for } \\
\text { small transactions }\end{array}$ & $\begin{array}{l}\text { Paper based notebook for information gathering, } \\
\text { writing \& communication }\end{array}$ \\
\hline 3 & $\begin{array}{l}\text { Generation X } \\
(1965-1979)\end{array}$ & $\begin{array}{l}\text { Watch TV \& Facebook } \\
\text { users, Tec savvy but } \\
\text { prefers personal } \\
\text { transactions and }\end{array}$ & $\begin{array}{l}\text { Xerox /Copying for information storage and } \\
\text { telephone technology for communication }\end{array}$ \\
\hline
\end{tabular}

\section{GENERATION Y \& HE STRATEGIES :}

Generation $Y$ also called millennials, born between 1980 and 1994 during the boom in technology. This tech-generation shows liberal in spending, insanely tech-savvy, self-expressive, confident, and open to new ideas and innovative ways of doing things. Currently, they are in the age between 25 to 40 years. Some of the traits of generation Y are :

(1) They are selfish, lazy, narcissistic and disloyal to higher authorities.

(2) They form the major part of the workforce and in the near future will become business leaders. 
(3) They are materialistic and care little about civil and political affairs.

(4) They are collecting information instantaneously from online and seeking validation on social media.

(5) They are tech-savvy and do many of the daily activities online.

(6) They are digital natives grown with technology such as internet, personal computer, and hence technology forms a central part of their lives.

(7) They used e-mail based communication, SMS based contacts, soft-copy of books and study materials, online exams in many cases.

(8) They inherit the confidence, dare-ness, and innovative ability from their predecessors, i.e., generation $\mathrm{X}$ and contributes to both technology and industry.
(9) They prefer flexibility in decisions and better performers in work life balance.

(10) They are usually ambitious and result oriented. They have high expectations at work and believe that there is no limit to what they can achieve.

Generation Y could able to get better opportunities for access to higher education as well as quality higher education [35-38]. The number of Higher education institutions were increased substantially during this period and the gross enrolment is also increased. The members of Tech-Generation $\mathrm{Y}$ could able to get information from all over the world through the internet and various search engines. Table 7 lists the frequently used education technology by Tech-Generation Y.

Table 7 : Habits and frequently use education technology of generation Y

\begin{tabular}{|c|c|c|c|}
\hline $\begin{array}{l}\text { S. } \\
\text { No. }\end{array}$ & Generation & Habits & Frequently used Education Technology \\
\hline 1 & $\begin{array}{l}\text { Generation Y (or } \\
\text { Millennials) } \\
(1980-1994)\end{array}$ & $\begin{array}{lr}\text { Cable based } & \text { Internet, } \\
\text { Internet } \\
\text { transactions }\end{array}$ & $\begin{array}{l}\text { Computer based copying, scanning, Processing \& } \\
\text { wired internet technology for communication }\end{array}$ \\
\hline
\end{tabular}

\section{GENERATION Z \& HE STRATEGIES :}

Tech-Generation Z also called Zoomer, or iGeneration, or Internet Generation is a group of people born between 1995 to 2015. They are also called Centennials [39-40].

Some of the traits of Tech-Generation $\mathrm{Z}$ are :

(1) Due to instantaneous information availability, they are less focussed in collecting information on anything and they update it using many internet based online sources.

(2) They developed skills to use many electronic gadgets without hesitation from childhood days so that they are capable to do many tasks simultaneously and hence considered as Multitaskers.

(3) They seek excitement in their job and does innovations through their creativity.

(4) Tech-Generation $Z$ is very intelligent and many of them have research thinking ability and hence teaching them both at school level and college level are challenging.

(5) Generation $\mathrm{Z}$ spends more time online and communicates in short messages in short format instead of long form of messages. They prefer messages through WhatsApp instead on sending long e-mails.

(6) Facebook and WhatsApp status are commonly used mass communication methods.

(7) They prefer to play mobile or video gaming for relaxation instead of real games on playgrounds.

(8) Tech-Generation $\mathrm{Z}$ students wants to design their own education plan and like to enhance skills along with concepts.

(9) Generation Z students are more careful in spending money compared to their previous generations.

(10) Though, Generation Z students are very reliant on social media for communication, research indicates that they prefer to work in team settings and also like to communicate in person.

Table 8 : Conflicts in time period range of the birth of Tech-Generation $\mathrm{Z}$

\begin{tabular}{|l|l|l|}
\hline S. & Birth time period range of Generation Y & Reference [41] \\
No. & & \\
\hline
\end{tabular}




\begin{tabular}{|l|l|l|}
\hline 1 & 1990 to 2000 & Merriam-Webster Online Dictionary \\
\hline 2 & $1997-2012$ & Oxford Living Dictionaries \\
\hline 3 & 1995 onwards & Psychologist Jean Twenge \\
\hline 4 & $1995-2010$ & Forbes \\
\hline 5 & $1995 \&$ above & Goldman Sachs, 2018 \\
\hline 6 & $1995-2009$ & Australia's McCrindle Research Centre \\
\hline 7 & $1995-2010$ & Irish Times \\
\hline 8 & 1995 onwards & BBC \\
\hline 9 & $1996-2010$ & Business Insider \\
\hline 10 & $1995-2014$ & Randstad Canada \\
\hline 11 & $1995-2015$ & Our definition [6] \\
\hline
\end{tabular}

Table 9 : Habits and frequently used education technology of generation $\mathrm{Z}$

\begin{tabular}{|l|l|l|l|}
\hline $\begin{array}{l}\text { S. } \\
\text { No. }\end{array}$ & Generation & Habits & Frequently used Education Technology \\
\hline 5 & $\begin{array}{l}\text { Generation Z } \\
\text { (or iGen or } \\
\begin{array}{l}\text { Centennials) } \\
(1995-2015)\end{array}\end{array}$ & $\begin{array}{l}\text { Mobile devices, Online } \\
\text { games, Mobile banking }\end{array}$ & $\begin{array}{l}\text { Online books \& Internet based information \& } \\
\text { communication using mobile devices }\end{array}$ \\
\hline
\end{tabular}

The present-day students in Universities are belonging to generation $\mathrm{Z}$ as derived from table 9, and they have the habit of using mobile devices for information communication, play online games using mobile devices and do online financial transactions using mobile devices. They use online books \& Internet based information \& communication technology using mobile devices. Accordingly, higher education offered by the universities have to change their curriculum, pedagogy, and models to be suitable for generation $Z$. Generation $\mathrm{Z}$ is introduced to online internetbased learning [42] and hence called net generation [43-44]. They are comfortable in digital supported learning using mobile devices [45-47].

10. NEXT GENERATIONS OF TECHNOLOGY, INDUSTRY, AND TECHHUMAN GENERATION BASED ON PREDICTIVE ANALYSIS :

As mentioned in section 3, the next generation technology is universal technology consisting of Information Communication and Computation Technology (ICCT) and Nanotechnology. ICCT comprising of about 12 underlying technologies that include: (1) Artificial intelligence \& robotics, (2) Big data \& intelligence, (3) Blockchain technology, (4) Cloud computing. (5) Cybersecurity technology, (6) 3D Printing, (7)
Digital \& Mobile technology, (8) Internet of Things (IoT), (9) Information storage technology, (10) Online Education technology, (11) Quantum computing, (12) Virtual \& Augmented reality, etc. These ICCT and nanotechnology are combinedly called Universal technology and predicted to have substantial effect and control on primary, secondary, tertiary, and quaternary industries. Artificial Intelligence a prominent underlying technology of ICCT is expected to grow in such a way that its advancement leads to the development of machines which have higher intelligence than human intelligence. Such machines called superintelligent machines are predicted to be developed at least by the year 2040. Such machines are capable to automate all primary and secondary and tertiary industries by solving all basic human needbased problems, wants based problems, and desirebased problems.

Artificial Intelligence is a branch of ICCT that deals with the simulation of intelligent behaviour of human beings. In the attempt of simulating human cognitive processes by machines and systems, it uses learning, reasoning, and selfcorrection of errors and malfunctions. AI integrates many areas of knowledge from computing, mathematics, and data to psychology, philosophy, and linguistics. When used along with other ICCT underlying technologies, AI can do marvellous in 
machines and systems performance by mimicking

human intelligence while making decisions.

Table 10 : Predictive analysis on technology, industry, education and Tech-generation of $21^{\text {st }}$ Century

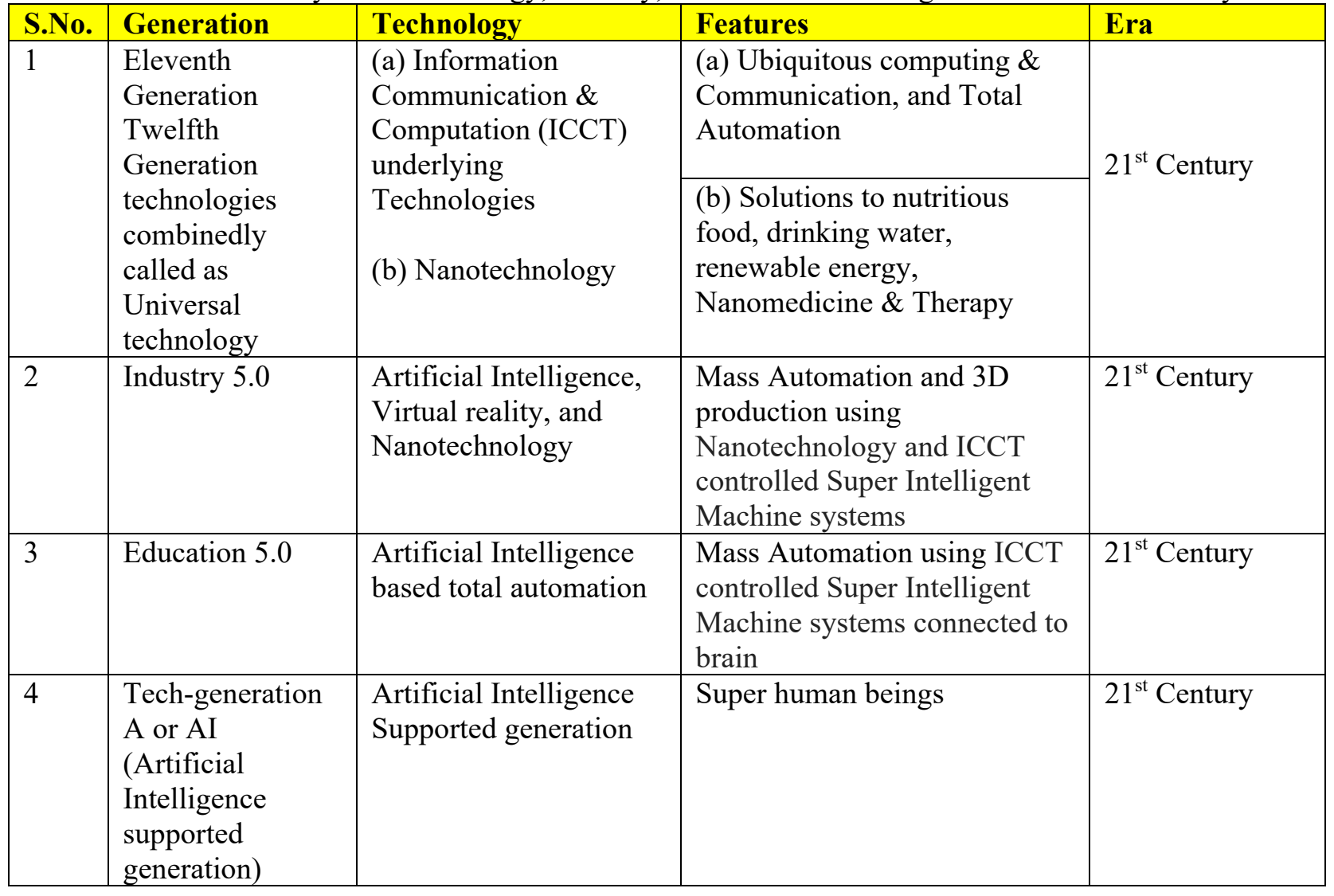

\section{GENERATION A \& ITS OPPORTUNITIES:}

Generation A or Tech-Generation A is a cohort of children born after 2015. They will do their education which is mostly influenced by ICCT underlying technologies headed by Artificial Intelligence and augmented \& virtual reality. This period will continue till super intelligent machines which can think faster than human intelligence. The perception and thinking of tech-generation A is highly influenced by environmental technologies used for simulation of reality as per their dreamy desires. As per table 10, Generation A uses artificial intelligence and virtual reality embedded mobile devices for their educational training and entertainment.

Since the generation grows with ICCT underlying technologies during their primary, high school and higher education, they will be tech-embedded and intelligent lazy people. When they become young, most of the basic problems (needs) related to nutritious food and potable drinking water are solved by advents in nanotechnology. Their comfortable problems or wants related to renewable energy and health will be solved using nanotechnology and biotechnology innovations. The requirement for satisfying their dreamy desires can be realized using ICCT underlying technologies including Artificial intelligence and virtual reality. Both the education phase and professional life phase of Generation A can be fully supported and automated by artificial intelligence based super intelligent machines. Many new inventions like production of artificial food, potable drinking water from the air, efficient conversion of solar energy and efficient storage of electrical energy, genetic modification for enhancing resistance to any diseases, artificial organs regeneration, lifespan expansion, creating superhuman beings, etc are going to take place during this period leading to technological 
heaven on earth. The time period during 2020 to 2050, many technological transformations are going to happen and Tech-generation A is going to be direct beneficiaries of such changes and they are going to adopt such changes in the society.

Table 11 : Habits and frequently use education technology of Generation A using Artificial Intelligence

\begin{tabular}{|l|l|l|l|l|}
\hline $\begin{array}{l}\text { S. } \\
\text { No. }\end{array}$ & Generation & Born Period & Habits & $\begin{array}{l}\text { Frequently used Education } \\
\text { Technology }\end{array}$ \\
\hline 1 & $\begin{array}{l}\text { Generation A } \\
\text { (Artificial } \\
\text { intelligence } \\
\text { generation) }\end{array}$ & $\begin{array}{l}2016 \\
\text { onwards }\end{array}$ & $\begin{array}{l}\text { Use of Artificial } \\
\text { Intelligence and virtual } \\
\text { reality embedded mobile } \\
\text { devices for education } \\
\text { and entertainment. }\end{array}$ & $\begin{array}{l}\text { Intelligent machines \& super } \\
\text { intelligent machine based virtual } \\
\text { reality \& Augmented virtual } \\
\text { reality educating technology } \\
\text { models }\end{array}$ \\
\hline
\end{tabular}

\section{HIGHER EDUCATION STRATEGIES TO BE PLANNED \& IMPLEMENTED FOR GENERATION A :}

Generation A will enter to the higher education after the year 2028 and by that time research in Artificial intelligence reaches the matured stage and hence artificial intelligence and virtual reality embedded mobile devices are part and parcel of their higher education teaching, training, and learning medium. To provide suitable higher education for current and future generations, universities should redefine their education system so that they can become relevant. Adopting artificial intelligence in the education system provides an easy way of knowledge management and redefines the teaching-learning process and evaluation system more learner friendly and avoids the importance of memorizing or byhearting many things simultaneously for the examination [6]. The augmented and virtual reality technology allows the learners to solve problems or to visualize the possible solutions virtually and allows to determine various dimensions of a problem without spending tangible resources in reality. It is argued that AI techniques are less expensive and more effective to higher education and contributing to improve learning outcomes and helping institutions to provide quality education [48]. Some of the advantages and benefits of Artificial intelligence based ICCT underlying technologies in higher education innovations are listed below :

(1) Artificial intelligence helps universities for student acquisition by providing personalized assistance ubiquitously for targeted admission. Hence it can help higher education institutions to achieve higher enrolment and retention of students.
(2) It can empower institutions to pinpoint student issues earlier and intervene proactively.

(3) Artificial intelligence helps faculty members to spend more time with students on a deep level along with grading and supplying basic resources for students.

(4) Machine-learning algorithms could help model the ideal student profile, and recruit matching prospects with extreme precision.

(5) AI can be used to predict the likelihood of a student engaging with an email or to gain deeper insights into how prospects are talking about your institution on social media through intelligent sentiment analysis.

(6) Using AI, students can get assistance such as tutoring or advising based on their previous and predicted future academic performance.

(7) AI can recommend the next best actions for your recruiting, advising and alumni engagement teams based on intelligent insights and pattern recognition.

(8) AI can use information about a student from many campuses to guide hiring decisions by an employer.

(9) Across every department and throughout the lifecycle, AI-powered bots and assistants could take on more daily tasks, so staff can focus on what matters most: student success.

(10) The subfield of artificial learning called machine learning that includes software which are capable of recognizing patterns, make predictions and apply them to situations which were not included in the initial design.

(11) AI automated solutions aim to find a new pedagogical philosophy that can help students achieve the set of skills required to live smartly in the twenty-first century [49]. 
(12) AI solutions are capable to identify our choices, preferences, movements, measuring strengths, and weaknesses, providing feedback, encouragement by providing customized news, alerts, so that take part to manage our lives [5056].

(13) Virtual and augmented reality provides visual, immersive learning, and deep learning experiences. For example, engineering and architecture students can build digital structures virtually, history students can build ancient historical ruins, and marine biology students build ocean floors, forensic science students can build murder cases for searching clues, etc. for their immersive education.

(14) Virtual reality allows teachers to train their students by new way through virtual travel, create virtual art, and virtual dissects of animals and cadaver. Use of virtual reality into the curriculum will help teachers to supplement their talents with that of experts in virtual technology. When combined with social media, virtual reality has the potential to connect learners with the world and each other in ways never before realized. The classroom buildings, libraries, and shared academic spaces may someday provide physical grids or open sound stages designed for virtual interaction, where groups of students may take guided field trips to remote sites, interface with other cultures, or travel in time. The teacher may guide the conversation, identifying important concepts and features, and posing questions.

(15) Students with physical disabilities or financial disadvantages can get access to imagined places and experiences like never before. Students may also be able to experience things that can only be theorized about, such as journeying into a black hole or flying through a strand of DNA. But the real promise of virtual reality in higher education lies in its ability of interactive learning [57-58].

\section{ANTICIPATED TECHNOLOGICAL \&CREATIVE INNOVATIONS OF GENERATION A :}

Generation A will be contributing and witnessing the discoveries and breakthroughs in $21^{\text {st }}$ century technologies. They will also enjoy the industrial applications of these eleventh and twelfth generation technologies for improving the comfortability of life. Generation A will learn these $21^{\text {st }}$ century technologies from their high schools and get benefits to convert them to be super techsavvy students of higher education and research.

\subsection{Artificial Intelligence based ICCT as a} Technology Generation :

The advents in artificial intelligence have the potential to transform our future into a new kind where machines eventually outsmart us at all tasks, replacing humans on the job market and perhaps human life will flourish like never before or give us more power than we can handle. Some of the artificial techniques like artificial creativity, Feelings recognition in Social media and marketing, understanding human language and converting desirable action, recognizing human problems and finding suitable and acceptable solutions. At its peak stage, AI machines can do everything to humans as his slave due to their ability to think and decide better than many human beings, so that people need not do any work for their livelihood [59-60].

\subsection{Artificial Intelligence based Education Industry as Education 5.0 :}

Artificial intelligence is expected to play a vital role in 21 st century education industry. Both lower (primary \& high school) and higher education modes, teaching \& training methods, pedagogy, evaluation approaches are predicted to be influenced by artificial intelligence technology, concepts, and systems. The data-driven development of education through Learning Analytics in combination with Artificial Intelligence is an emerging field in the education sector. It has the ability and potential to identify the student who failed to understand the concepts so that alternative techniques for teaching and learnings can be used for such slow phase students. AI can find a reason for low performance in tests or examinations based on psychological counseling and in turn, increases the higher education enrolment ratio. The impact of such changes in the education industry 5.0 is predicted by several researchers [61-63]. The opportunities and challenges of AI in education for a sustainable, and progressive society, impact on knowledge assessment and creative thinking are also predicted [64-66].

\subsection{Artificial Intelligence based Human}




\section{Generation as a new Tech-Generation :}

Since the Tech-Generation A born from the year 2016 is going to be a direct beneficiary of advents in Artificial intelligence and other underlying technologies of ICCT and Nanotechnology. The COVID-19 effect is expected to adopt AI techniques forcefully in elementary, high school, and college education. This change supports the positive development of accepting these latest technologies in the day-to-day education system in society so that children are going to be exposed to the latest technology applications and hence the way of thinking which will be completely different compare to their previous tech-generations. The children equipped with high tech mobile devices and access to the latest developments in technology will become super tech-savvy and equip themselves to contribute to the process of research and innovations on developing super intelligent machines which are capable to make faster and optimum decisions compared to human beings.

\section{POSTULATES, PRECAUTIONS, \& SUGGESTIONS TO GENERATION A EDUCATION MODEL :}

Based on the above arguments of next generation technology, next generation industry, next generation education, and next Tech-Human generation, we propose the following postulates based on our predictive analysis principles [67-68]

(1) $21^{\text {st }}$ century will witness the mega performance of two technology generations - ICCT and Nanotechnology where Artificial Intelligence is going to be a major contributor to transforming society.

(2) $21^{\text {st }}$ century Industry generation called Industry 5.0 is going to get benefit from Artificial Intelligence and nanotechnology for mass automation and 3D production in the manufacturing sector and AI based service automation in the service sector.

(3) $21^{\text {st }}$ century Education generation called Education 5.0 is going to take benefit from Artificial Intelligence along with other ICCT underlying technologies to modify education methods and customize education pedagogy.

(4) $21^{\text {st }}$ century human generation called TechGeneration A will get benefits while availing education at school and college levels substantially through Artificial Intelligence technology and enjoy the power of autonomous machines which gets intelligence level higher than human intelligence.

(5) $21^{\text {st }}$ century is expected to provide major transformation in human civilization and lifestyle by solving their basic needs, advanced wants, and dreamy desires using two general purpose ICCT and Nanotechnology, combinedly called Universal Technologies.

\section{Precautions :}

Every technology has its own disadvantage if misused by anyone or by organizations. The autonomous decisions are taken by AI systems and applications sometimes dangerous for organizations and society due to any system malfunction. AI applications pose risks to issues like privacy, human rights, autonomy of organizations, individual liberties which must be carefully addressed. AI based higher education strategies may create division in the people of society as super Tech-savvy and non-tech-savvy with a wide gap in perception and thinking about comfortability in life. Automation of almost all decisions in individual life may create more challenges of individual behaviour towards social issues and the need for psychological counseling may be a common requirement.

\section{Suggestions :}

Based on the above conceptual analysis on the future higher education system, which is technology driven and new tech-generation driven, need to adopt many changes in their business models [69-71]. The predictive analysis suggests the following strategies:

(1) Educational organizations while planning their strategy for future education models, modes, methods, and pedagogy, should keep the changes happening in Technology, Industry, and attitude and behaviour of super tech-savvy generation (Tech-generation A) in mind.

(2) To cope up with future challenges on online customized education which is the aim of Education 5.0, the higher education institutions should focus more on strategies related to differentiating themselves in the competitive online education market.

(3) Another challenge of AI in automated 
customized education supports only a few Universities in higher education space. This is because Higher Education is going to be a highcost, High-Tech industry and needs huge investment for providing mass customized automated higher education all over the world.

research

(4) Higher education institutions can come out from the challenges of intensive competition and subsequent possible closure due to "Industry support for only a few Universities" like Aeroplane manufacturing industry. This is further due to required heavy investments in technologycontrolled education, which can be countered by following a strategy of Research based university differentiation by adding innovative research components in the higher education curriculum.

(5) Higher education Institutions should foresee the future changes in people aspiration due to penetration of AI and other underlying technologies to their industry, and adopt changes in their business models, will become obsolete and die-down eventually.

\section{CONCLUSION :}

Advents in technology and its effects on transforming society plays a vital role in human life in society. Though Generation S, Generation B, Generation X, Generation Y, and Generation Z are available in the literature, Generation $A$ is introduced first time by our group to represent the people born after 2015 and is the witness of developments in artificial intelligence and other ICCT underlying technologies in daily life as well as in their education process. Higher educational institutions are being transformed by intelligent systems that are helping students to learn better by achieving their learning objectives. The areas of artificial intelligence including intelligent tutors, personalized trainers, smart advisors, learning analytics, are already achieved. In this conceptual analysis, we have developed a set of postulates that are suggested to integrate technology in the higher education process to develop industry acceptable qualified professionals in higher education to serve satisfactorily in so called Tech-society. Some of the new names coined to explain the current and future changes due to continuous advances in technology and its reflection in the society are listed in the concluding table 12.

Table 12 : New names Coined in this analysis

\begin{tabular}{|c|c|c|c|}
\hline S. No. & Issue & Name & First Time Named by \\
\hline 1 & $\begin{array}{l}\text { Classification of } \\
\text { Technology in the form of } \\
\text { Generations }\end{array}$ & $\begin{array}{l}12 \text { technology generations } \\
\text { reported }\end{array}$ & $\begin{array}{l}\text { Aithal, P. S. in this Scholarly } \\
\text { Article }\end{array}$ \\
\hline 2 & $\begin{array}{l}\text { Future Industry } 5.0 \text { and its } \\
\text { Technology }\end{array}$ & $\begin{array}{l}\text { Mass Automation using } \\
\text { Nanotechnology and ICCT } \\
\text { controlled Super Intelligent } \\
\text { Machine systems - Intelligence } \\
\text { based. }\end{array}$ & P. S. Aithal et al. (2020) [6] \\
\hline 3 & $\begin{array}{l}\text { Future Education } 5.0 \text { and its } \\
\text { effecting Technology }\end{array}$ & $\begin{array}{l}\text { Mass Automation of education } \\
\text { using Nanotechnology and ICCT } \\
\text { controlled Super Intelligent } \\
\text { Machine systems }\end{array}$ & Aithal, P. S. et al. (2020) [6] \\
\hline 4 & $6^{\text {th }}$ Tech-Generation & $\begin{array}{l}\text { Generation A } \\
\text { or Generation AI }\end{array}$ & Aithal, P. S. et al. (2020) [6] \\
\hline 5 & Universal Technology & ICCT and Nanotechnology & Aithal P. S. et al. (2019) [4] \\
\hline
\end{tabular}

\section{REFERENCES :}

[1] Aithal P. S. \& Suresh Kumar P. M. (2018). Approaches to Confidence Building as a Primary
Objective in Postgraduate Degree Programmes. International Journal of Applied Engineering and Management Letters (IJAEML), 2(1), 64-71. DOI: http://dx.doi.org/10.5281/zenodo.1205185. 
[2] Aithal, P. S. \& Madhushree, L. M. (2019). Information Communication \& Computation Technology (ICCT) as a Strategic Tool for Industry Sectors. International Journal of Applied Engineering and Management Letters (IJAEML), 3(2), 65-80. DOI: http://doi.org/10.5281/zenodo.3549423.

[3] Aithal, P. S., \& Shubhrajyotsna Aithal, (2015). Ideal Technology Concept \& its Realization Opportunity using Nanotechnology, International Journal of Application or Innovation in Engineering \& Management (IJAIEM), 4(2), 153 164. DOI: http://doi.org/10.5281/zenodo.61591.

[4] Aithal, P. S. and Shubhrajyotsna Aithal. (2018). Study of various General-Purpose Technologies and their contribution towards developing Sustainable Society. International Journal of Management, Technology, and Social Sciences (IJMTS), $\quad 3(2), \quad 16-33 . \quad$ DOI :http://doi.org/10.5281/zenodo.1409476.

[5] Aithal P. S.\& Shubhrajyotsna Aithal (2018). Nanotechnology based Innovations and Human Life Comfortability -Are we Marching towards Immortality ? International Journal of Applied Engineering and Management Letters (IJAEML), 2(2), 71-86. DOI :https://doi.org/10.5281/zenodo.1451498.

[6] Aithal P. S., \& Aithal Shubhrajyotsna (2020). Promoting Faculty and Student-Centered Research and Innovation based Excellence Model to Reimage Universities. International Journal of Management, Technology, and Social Sciences (IJMTS), 5(1), 24-41. DOI: http://doi.org/10.5281/zenodo.3702399.

[7] Madhushree, L. M., Revathi Radhakrishnan \& Aithal, P. S. (2019). A Review on Impact of Information Communication \& Computation Technology (ICCT) on Selected Primary, Secondary, and Tertiary Industrial Sectors. Saudi Journal of Business and Management Studies, 4(1), 106-127. DOI: http://doi.org/10.21276/sjbms.2019.4.1.14.

[8] Aithal, P. S. \& Madhushree L. M. (2019). Emerging Trends in ICCT as Universal Technology for Strategic Development of Industry Sectors. Chapter in a Book - IT and Computing for all the Domains and Professionals: The Emergence of Computer and Information Sciences, Edited by P.K. Paul, A. Bhuimali, K.S. Tiwary, and P. S. Aithal published by New Delhi Publishers, New Delhi. pp 1-26, ISBN: 978-93-88879-66-8. DOI :https://doi.org/10.5281/zenodo.3593916.

[9] Aithal, P. S. \& Shubhrajyotsna Aithal (2019). Management of ICCT underlying Technologies used for Digital Service Innovation. International Journal of Management, Technology, and Social Sciences (IJMTS), 4(2), 110-136. DOI :http://doi.org/10.5281/zenodo.3591139.

[10] Sackmann, R., \& Winkler, O. (2013). Technology generations revisited: The internet generation. Gerontechnology, 11(4), 493-503.

[11] Combes, B. A. (2012). Tech savvy or tech oriented? Information-seeking behaviour and the Net Generation (Doctoral dissertation, Curtin University).

https://pdfs.semanticscholar.org/1ba5/3dcbc09fca a3c00e3b3f4487f4d6f4c2b619.pdf

[12] Kupperschmidt, B. R. (1998). Understanding generation $\mathrm{X}$ employees. JONA: The Journal of Nursing Administration, 28(12), 36-43.

[13] Brown, B. L. (1997). New learning strategies for generation $X$ (Vol. 184). ERIC Clearinghouse on Adult, Career, and Vocational Education, Center on Education and Training for Employment, College of Education, the Ohio State University.

[14] Cannon, D. (1991). Generation X: The Way They Do the Things They Do. Journal of Career Planning and Employment, 51(2), 34-38.

[15] Ferres, N., Travaglione, A., \& Firns, I. (2003). Attitudinal differences between generation-x and older employees. International Journal of Organisational Behaviour, 6(3), 320-333.

[16] Losyk, B. (1997). Generation X: What they think and what they plan to do. The futurist, 31(2), 39.

[17] Eisner, S. P. (2005). Managing generation Y. SAM Advanced Management Journal, 70(4), 4.

[18] VanMeter, R. A., Grisaffe, D. B., Chonko, L. B., \& Roberts, J. A. (2013). Generation Y's ethical ideology and its potential workplace implications. Journal of business ethics, 117(1), 
93-109.

[19] Meier, J., \& Crocker, M. (2010). Generation $\mathrm{Y}$ in the workforce: Managerial challenges. The Journal of Human Resource and Adult Learning, 6(1), 68.

[20] Solnet, D., Kralj, A., \& Kandampully, J. (2012). Generation Y employees: An examination of work attitude differences. Journal of Applied Management and Entrepreneurship, 17(3), 36.

[21] Wolburg, J. M., \& Pokrywczynski, J. (2001). A psychographic analysis of Generation Y college students. Journal of advertising research, 41(5), 33-52.

[22] Eckleberry-Hunt, J., \& Tucciarone, J. (2011). The challenges and opportunities of teaching "Generation Y". Journal of graduate medical education, 3(4), 458-461.

[23] Pînzaru, F., VĂTĂMĂNESCU, E. M., Mitan, A., SĂVULESCU, R., VIȚELAR, A., Noaghea, C., \& BĂLAN, M. (2016). Millennials at work: Investigating the specificity of generation $\mathrm{Y}$ versus other generations. Management Dynamics in the Knowledge Economy, 4(2), 173-192.

[24] Shatto, B., \& Erwin, K. (2016). Moving on from millennials: Preparing for generation $\mathrm{Z}$. The Journal of Continuing Education in Nursing, 47(6), 253-254.

[25] Singh, A. P., \& Dangmei, J. (2016). Understanding the generation $\mathrm{Z}$ : the future workforce. South-Asian Journal of Multidisciplinary Studies, 3(3), 1-5.

[26] Dolot, A. (2018). The characteristics of Generation Z. E-mentor, 74(2), 44-50.

[27] Iorgulescu, M. C. (2016). Generation Z and its perception of work. Cross-Cultural Management Journal, 18(01), 47-54.

[28] Shatto, B., \& Erwin, K. (2017). Teaching Millennials and Generation Z: Bridging the generational divide. Creative nursing, 23(1), 2428.

[29] Berkup, S. B. (2014). Working with generations $\mathrm{X}$ and $\mathrm{Y}$ in generation $\mathrm{Z}$ period: Management of different generations in business life. Mediterranean Journal of Social
Sciences, 5(19), 218-218.

[30] Mohr, K. A., \& Mohr, E. S. (2017). Understanding Generation $\mathrm{Z}$ students to promote a contemporary learning environment. Journal on Empowering Teaching Excellence, 1(1), 9.

[31] Cilliers, E. J. (2017). The challenge of teaching generation Z. PEOPLE: International Journal of Social Sciences, 3(1), 188-198.

[32] Cruz, F. J. F., \& Díaz, M. J. F. (2016). Generation z's teachers and their digital skills. Comunicar. Media Education Research Journal, 24(1), 97-105.

[33] Nagy, Á., \&Kölcsey, A. (2017). Generation Alpha: marketing or science. Acta Educationis Generalis, 7(1), 107-115.

[34] Jorgensen, B. (2003). Baby Boomers, Generation $\mathrm{X}$ and Generation $\mathrm{Y}$ ? Policy implications for defence forces in the modern era. Foresight, 5(4), 41-49.

[35] Wilson, M., \& Gerber, L. E. (2008). How generational theory can improve teaching: strategies for working with the millennials. Currents in teaching and learning, 1(1), 29-44.

[36] Battersby, L. (2017). Education strategies that best engage Generation Y students. Canadian Journal of Dental Hygiene, 51(3).

[37] Aksoy, L., Van Riel, A., Kandampully, J., Bolton, R. N., Parasuraman, A., Hoefnagels, A., ... \& Solnet, D. (2013). Understanding Generation Y and their use of social media: a review and research agenda. Journal of service management.

[38] Eisner, S. P. (2005). Managing generation Y. SAM Advanced Management Journal, 70(4), 415.

[39] Töröcsik, M., Szücs, K., \& Kehl, D. (2014). How generations think: research on generation z. Acta universitatis Sapientiae, communicatio, 1(1), 23-45.

[40] Seemiller, C., \& Grace, M. (2017). Generation $\mathrm{Z}$ : Educating and engaging the next generation of students. About Campus, 22(3), 21-26.

[41] Strauss, W., \& Howe, N. (1991). Generation Z. http://incomeresult.com/generation-Z/ 
[42] Lee, M. K., Cheung, C. M., \& Chen, Z. (2005). Acceptance of Internet-based learning medium: the role of extrinsic and intrinsic motivation. Information \& management, 42(8), 1095-1104

[43] Barnes, K., Marateo, R. C., \& Ferris, S. P. (2007). Teaching and learning with the net generation. Innovate: Journal of Online Education, 3(4).

[44] Kolikant, Y. B. D. (2010). Digital natives, better learners? Students' beliefs about how the Internet influenced their ability to learn. Computers in Human Behavior, 26(6), 1384-1391.

[45] Desai, S. P., \& Lele, V. (2017). Correlating internet, social networks and workplace-A case of Generation Z students. Journal of Commerce and Management Thought, 8(4), 802-815.

[46] Seemiller, C., \& Grace, M. (2017). Generation $\mathrm{Z}$ : Educating and engaging the next generation of students. About Campus, 22(3), 21-26.

[47] Madhushree L. M., Pradeep M. D.\& Aithal, P. S. (2019). Boosting Education through Mobile Technology in India - Study with reference to Generation Z. International Journal of Applied Engineering and Management Letters (IJAEML), 3(2), 96-105. DOI: http://doi.org/10.5281/3597588.

[48] Garrison, D. R., \& Akyol, Z. (2009). Role of instructional technology in the transformation of higher education. Journal of Computing in Higher Education, 21(1), 19-28.

[49] Popenici, S.A.D., Kerr, S. (2017). Exploring the impact of artificial intelligence on teaching and learning in higher education. RPTEL, 12, 22. DOI: https://doi.org/10.1186/s41039-017-0062-8.

[50] Popenici, S. A., \& Kerr, S. (2017). Exploring the impact of artificial intelligence on teaching and learning in higher education. Research and Practice in Technology Enhanced Learning, 12(1), 22-29.

[51] Chassignol, M., Khoroshavin, A., Klimova, A., \& Bilyatdinova, A. (2018). Artificial Intelligence trends in education: a narrative overview. Procedia Computer Science, 136, 16-
24.

[52] Colchester, K., Hagras, H., Alghazzawi, D., \& Aldabbagh, G. (2017). A survey of artificial intelligence techniques employed for adaptive educational systems within e-learning platforms. Journal of Artificial Intelligence and Soft Computing Research, 7(1), 47-64.

[53] Roll, I., \& Wylie, R. (2016). Evolution and revolution in artificial intelligence in education. International Journal of Artificial Intelligence in Education, 26(2), 582-599.

[54] Edwards, B. I., \& Cheok, A. D. (2018). Why not robot teachers: artificial intelligence for addressing teacher shortage. Applied Artificial Intelligence, 32(4), 345-360.

[55] Bajaj, R., \& Sharma, V. (2018). Smart Education with Artificial Intelligence based Determination of Learning Styles. Procedia computer science, 132, 834-842.

[56] Luckin, R. (2017). Towards artificial intelligence-based assessment systems. Nature Human Behaviour, 1(3), 1-3.

[57] Lee, K. (2012). Augmented reality in education and training. TechTrends, 56(2), 13-21.

[58] Kavanagh, S., Luxton-Reilly, A., Wuensche, B., \& Plimmer, B. (2017). A systematic review of Virtual Reality in education. Themes in Science and Technology Education, 10(2), 85-119.

[59] Popkova, E. G., \& Gulzat, K. (2019, May). Technological Revolution in the 21 st Century: Digital Society vs. Artificial Intelligence. In Institute of Scientific Communications Conference (pp. 339-345). Springer, Cham.

[60] Makridakis, S. (2017). The forthcoming Artificial Intelligence (AI) revolution: Its impact on society and firms. Futures, 90, 46-60.

[61] Popenici, S. A., \& Kerr, S. (2017). Exploring the impact of artificial intelligence on teaching and learning in higher education. Research and Practice in Technology Enhanced Learning, 12(1), 22.

[62] Roll, I., \& Wylie, R. (2016). Evolution and revolution in artificial intelligence in education. International Journal of Artificial 
Intelligence in Education, 26(2), 582-599.

[63] Holmes, W., Bialik, M., \& Fadel, C. (2019). Artificial intelligence in education. Boston: Center for Curriculum Redesign.

[64] Pedro, F., Subosa, M., Rivas, A., \& Valverde, P. (2019). Artificial intelligence in education: Challenges and opportunities for sustainable development.

[65] Cope, B., Kalantzis, M., \& Searsmith, D. (2020). Artificial intelligence for education: Knowledge and its assessment in AI-enabled learning ecologies. Educational Philosophy and Theory, 1-17.

[66] Nagao, K. (2019). Artificial Intelligence in Education. In Artificial Intelligence Accelerates Human Learning (pp. 1-17). Springer, Singapore.

[67] Shuhrajyotsna Aithal \& Aithal, P. S. (2018). The Realization Opportunity of Ideal Energy System using Nanotechnology Based Research and Innovations. International Journal of Advanced

Trends in Engineering and Technology, 3(2), 1-15. DOI: http://doi.org/10.5281/zenodo.2531876.

[68] Aithal, P. S. \& Shubhrajyotsna Aithal (2019). Building World-Class Universities : Some Insights \& Predictions. International Journal of Management, Technology, and Social Sciences (IJMTS), 4(2), 13-35. DOI: http://doi.org/10.5281/zenodo.3377097.

[69] Clarke, Steve. "Future technologies, dystopic futures and the precautionary principle." Ethics and Information technology 7.3 (2005): 121-126.

[70] Clarke, S. (2009). New technologies, common sense and the paradoxical precautionary principle. In Evaluating New Technologies (pp. 159-173). Springer, Dordrecht.

[71] Yudkowsky, E. (2008). Artificial intelligence as a positive and negative factor in global risk. Global catastrophic risks, 1(303), 184. 